\title{
Cooking Effects on Iron and Proteins Content of Beans (Phaseolus Vulgaris L.) by GF AAS and MALDI-TOF MS
}

\author{
Juliana Naozuka*,a and Pedro V. Oliveira ${ }^{b}$ \\ ${ }^{a}$ Universidade Federal de São Paulo, Diadema-SP, Brazil \\ ${ }^{b}$ Departamento de Química Fundamental, Instituto de Química, Universidade de São Paulo, São Paulo-SP, Brazil
}

\begin{abstract}
Os efeitos do cozimento doméstico na distribuição de proteínas, compostos orgânicos e Fe em feijão (Phaseolus vulgaris L.) foram investigados. Extração seqüencial com diferentes agentes extratores (mistura de metanol e clorofórmio 1:2 v/v, água, $\mathrm{NaCl}$, etanol e $\mathrm{NaOH}$ ) foi usada para extrair lipídeos, albuminas, globulinas, prolaminas e glutelinas, respectivamente. A determinação de Fe por espectrometria de absorção atômica com forno de grafite (GF AAS), de proteínas pelo método de Bradford e compostos orgânicos por espectrometria de massas por tempo de vôo acoplada à ionização dessortiva de matriz por laser (MALDI-TOF MS) foram feitas nesse trabalho. Altas concentrações de albuminas, globulinas e glutelínas foram encontradas em feijão cru, enquanto que em grãos cozidos, albuminas e glutelínas foram os principais tipos de proteínas. Os espectros de MALDI-TOF MS do feijão cru e cozido revelaram que o cozimento doméstico alterou os pesos moleculares dos compostos orgânicos, uma vez que nos grãos cozidos foram encontrados compostos entre 2 e 3,5 kDa, os quais não estavam presentes no feijão cru. Além disso, no feijão cozido foi também observada a presença de quatro compostos de alto peso molecular (12-16 kDa), sendo que em grãos crus há somente um ( $c a .15,2 \mathrm{kDa})$. Nos grãos crus foi possível observar que Fe está principalmente associado a albuminas, globulinas e glutelínas. Para os grãos cozidos, Fe está presente em alta concentração em albuminas e globulinas.
\end{abstract}

The effects of domestic cooking on proteins, organic compounds and Fe distribution in beans (Phaseolus vulgaris L.) were investigated. Sequential extraction with different extractant solutions (mixture of methanol and chloroform 1:2 v/v, water, $0.5 \mathrm{~mol} \mathrm{~L}^{-1} \mathrm{NaCl}, 70 \% \mathrm{v} / \mathrm{v}$ ethanol and $\left.0.5 \mathrm{~mol} \mathrm{~L}{ }^{-1} \mathrm{NaOH}\right)$ were used for extracting lipids, albumins, globulins, prolamins and glutelins, respectively. Iron determination by graphite furnace atomic absorption spectrometry (GF AAS), proteins by Bradford method and organic compounds by matrix-assisted laser desorption ionization time-of-flight mass spectrometry (MALDI-TOF MS) were carried out in this work. High concentration of albumins, globulins and glutelins were found in raw beans, while in the cooked beans, albumins and glutelins are main proteins types. The MALDI-TOF MS spectra of raw and cooked beans revealed that the domestic cooking altered the molecular weight of the organic compounds, since that in the cooked beans were found compounds between 2 and $3.5 \mathrm{kDa}$, which were not presented in the raw beans. Besides this, in cooked beans were also observed the presence of four compounds of high molecular weight (12-16 kDa), being that in the raw grains there is only one ( $c a .15 .2 \mathrm{kDa})$. In raw grains is possible to observe that $\mathrm{Fe}$ is mainly associated to albumins, globulins and glutelins. For cooked grains, Fe is associated to albumins and globulins.

Keywords: iron, proteins, beans, GF AAS, MALDI-TOF MS

\section{Introduction}

Beans (Phaseolus vulgaris L.) are a typical culture of tropical and subtropical weather. Brazil is the largest worldwide producer (2.2-2.5 million tons, in approximately 5 million hectares cultivated) and consumer (around

*e-mail: jnaozuka@gmail.com
$16 \mathrm{~kg}$ per capita). Beans is one of the richest foods in proteins consumed by the Brazilian population. ${ }^{1}$ Normally, countryside population is responsible for the high consumption of this food. ${ }^{1,2}$ However, consumption of beans is declining, due to the changes in traditional dietary habits of Brazilian population. ${ }^{2}$

Beans are a good source of vitamins, minerals (K, $\mathrm{Ca}, \mathrm{Mg}, \mathrm{P}$ and $\mathrm{Fe}$ salts), proteins (20-25\%) and complex 
carbohydrates (50-60\%)..$^{2-4}$ Besides their nutritional importance, beans contain certain anti-nutritional constituents, such as trypsin inhibitors, tannins, phytic acid and oligosaccharides that limit protein and carbohydrate absorption. $^{5}$

The heating of beans can increase the protein and starch digestibility from $25-60 \%$ (raw grains) to $85 \%$ (cooked grains), depending on the species and cooking procedure. ${ }^{6}$ Futhermore, cooking promotes the production of desirable sensory properties in beans, such as sweet taste, cookedbean flavor, and soft and mushy textures. ${ }^{2}$ However, cooking causes considerable changes in the composition of numerous chemical constituents, including amino acids, vitamins and minerals. ${ }^{3}$

The effects of cooking in the distribution of soluble iron were evaluated for legumes, beans, chickpeas and lentils. ${ }^{7}$ It was reported that cooking increases soluble iron contents presented in the cooking water. These studies are very important, because the heating can influence the iron bioavailability. It is generally accepted that only soluble non-heme iron can be absorbed. However, interactions with other compounds, such as anti-nutritional constituents, presented in the beans can also alter the iron bioavailability. Numerous studies have led to the conclusion that phytic acid and tannins may bind to proteins and some essential dietary minerals, making them unavailable or only partially available for absorption. ${ }^{8}$

Studies about heating effects in proteins and essential elements (e.g., $\mathrm{Fe}$ ) are still limited, especially for cultivars commonly consumed in Brazil, where beans are the staple food. Additionally, in Brazil there are some research aiming the enrichment of beans with essential elements, such as iron. Consequently, the elaboration of methodologies that allow the evaluation of the cooking effects in the distribution of proteins and elements is imperative, since cooking is required to eat beans. Considering the nutritional importance, the aim of this work was to evaluate the effects of domestic cooking in beans on proteins, organic compounds and $\mathrm{Fe}$ distribution. Sequential extraction with different extracting agents (e.g., water, $\mathrm{NaCl}$, ethanol and $\mathrm{NaOH}$ ) and $\mathrm{Fe}$, proteins and organic compounds determination by GF AAS, Bradford method ${ }^{9}$ and MALDI-TOF-MS, respectively, were used in this investigation.

\section{Experimental}

Instrumental

A ZEEnit 60 model atomic absorption spectrometer (AnalytikjenaAG, Jena, Germany) equipped with a transversely heated graphite atomizer, pyrolytically coated graphite tube, transversal Zeeman-effect background corrector was used for Fe determination. The spectrometer was operated using hollow cathode lamp. All measurements were based on integrated absorbance values. The instrumental conditions for the spectrometer and the heating program are shown in Table 1. Argon 99.998\%, v/v (Air Liquide Brasil, São Paulo, Brazil) was used as protective and purge gas.

Table 1. Instrumental parameters and heating program for $\mathrm{Fe}$ determination by GF AAS

\begin{tabular}{lccc}
\hline Instrumental parameters & $\mathrm{Fe}$ & & \\
\hline$\lambda / \mathrm{nm}$ & 248.3 & & \\
slit / nm & 0.8 & & \\
$\mathrm{I} / \mathrm{mA}$ & 4.0 & & \\
\hline Heating program & & & \\
\hline Step & $\mathrm{T} /{ }^{\circ} \mathrm{C}$ & $\mathrm{Ramp}^{\prime}\left({ }^{\circ} \mathrm{C} \mathrm{s}^{-1}\right)$ & $\mathrm{Hold} / \mathrm{s}$ \\
Dry I & 100 & 10 & 10 \\
Dry II & 130 & 10 & 15 \\
Pyrolysis & 1200 & 100 & 20 \\
Atomization & 2300 & 2300 & 5 \\
Cleaning & 2500 & 1200 & 2 \\
\hline
\end{tabular}

An Ultrospec 2100 pro spectrophotometer (Biochrom LTD, Cambridge, UK), equipped with xenon lamp and wavelength ranged to 190 from $900 \mathrm{~nm}$ was used for protein determination at $590 \mathrm{~nm}$.

The digestion of samples and reference certified material (CRM) were carried out in a closed vessel microwave oven, model Microwave 3000 (Anton Paar, Graz, Austria), equipped with 16 fluoropolymer vessels and a ceramic vessel jacket. They support a maximum temperature and pressure of $240{ }^{\circ} \mathrm{C}$ and $4 \mathrm{MPa}$, respectively. The internal temperature and pressure are monitored in only one controlling vessel using a sensor-protecting glass tube that enters directly into contact with digested solution. The external temperature is controlled in all vessels using an IR sensor, which measures each digestion vessel through ports in the rotor base.

An orbital shaker (Quimis, São Paulo, Brazil) was used to mix the samples and extracting agents using rotation velocity of $250 \mathrm{rpm}$ for $30 \mathrm{~min}$.

A vacuum filtration system of borosilicate glass, model XX15 04700 (Millipore, USA) and a $0.45 \mathrm{~mm}$ Nylon ${ }^{\circledast}$ membrane filter (Millipore, USA) and a model Q222TM centrifuge (Quimis, São Paulo, Brazil) were used to separate the supernatant of the solid material after extractions.

Matrix-assisted laser desorption ionization time-offlight mass spectrometry (MALDI-TOF-MS), model Ettan 
MALDI-TOF Pro MS (Amersham Biosciences, Uppsala, Sweden) was used for quantitative determination of organic species of beans after and before cooking.

\section{Reagents and samples}

All solutions were prepared with analytical reagent grade chemicals using high-purity deionized water obtained by Milli- ${ }^{\circledR}$ water purification system (Millipore, Bedford, USA). Nitric acid 65\% (m/v) (Merck, Darmstadt, Germany) distilled in a quartz sub-boiling still (Marconi, SP, Brazil) and $\mathrm{H}_{2} \mathrm{O}_{2} 30 \%(\mathrm{~m} / \mathrm{v})$ (Merck) were used for sample digestion. Tritisol ${ }^{\circledast}$ standard solution of $1000 \mathrm{mg} \mathrm{L}^{-1}$ of Fe (Merck) was used to prepare the reference analytical solutions by serial dilution in $0.14 \mathrm{~mol} \mathrm{~L}^{-1} \mathrm{HNO}_{3}$.

Analytical grade chloroform, ethanol, methanol, $\mathrm{NaCl}$ and $\mathrm{NaOH}$ (Merck) were used for solid-liquid extractions.

The total protein concentration in each extractant (water, $\mathrm{NaCl}$, ethanol and $\mathrm{NaOH}$ ) was determined using Bradford method. ${ }^{9}$ The Bradford reagent was prepared using $10 \mathrm{mg}$ of Coomassie Blue G-250, $5.0 \mathrm{~mL}$ of methanol and $10 \mathrm{~mL}$ of $85 \%(\mathrm{v} / \mathrm{v})$ phosphoric acid (Sigma). The final volume $(100 \mathrm{~mL})$ was completed with deionized water. The protein standard was prepared dissolving $4.0 \mathrm{mg}$ of ovoalbumin (BioAgency, São Paulo, Brazil) in $2.0 \mathrm{~mL}$ of deionized water, using Vortex stirring for $2 \mathrm{~min}$. Afterward this solution was 10-fold diluted with deionized water.

For MALDI-TOF MS analysis, the dialyzed fractions (water fraction) were adequately diluted in saturated solution of sinapinic acid (LaserBio Labs, France) in $50 \%(\mathrm{v} / \mathrm{v})$ acetronitrile (Merck, USA) and 0.5\% (v/v) trifluoroacetic acid (TFA, Fluka, Switzerland).

The bean, called "carioca", used in this research was purchased at local markets. Before analysis, sample was washed with deionized water several times.

Corn (SRM 8433) as certified reference material from NIST (National Institute of Standards and Technology, Gaithersburg, Maryland, USA) was used to check the entire accuracy of the analytical method.

\section{Sample digestion}

Sample mass ranging from 150 to $250 \mathrm{mg}$ were digested using a diluted oxidant mixture $\left(2 \mathrm{~mL} \mathrm{HNO}_{3}+1 \mathrm{~mL} \mathrm{H}_{2} \mathrm{O}_{2}+\right.$ $\left.3 \mathrm{~mL} \mathrm{H}_{2} \mathrm{O}\right) .{ }^{10}$ This mixture was submitted to digestion in a closed-vessel microwave system. The heating program was performed in three steps $\left(\right.$ Temperature $/{ }^{\circ} \mathrm{C}$; $\mathrm{ramp} / \mathrm{min}$; hold/min): $1(140 ; 5 ; 1) ; 2(180,4,5)$; and 3 $(220,4,10)$. There is a fourth step for cooling down the system through forced ventilation for a period of $20 \mathrm{~min}$.
After the digestion, samples (beans and corn bran) and analytical blank solutions were transferred to plastic flasks and made up to $10 \mathrm{~mL}$ with deionized water. Samples and CRM (corn) were digested in triplicate.

\section{Cooking procedure}

After cleaned with deionized water the beans were separated in two parts. The first portion was ground in a household food grinder and dried in stove at $60{ }^{\circ} \mathrm{C}$ until constant mass. The second portion ( $\mathrm{ca} .500 \mathrm{~g}$ ) was cooked in stainless steel pressure cooker in $1.0 \mathrm{~L}$ of deionized water for $40 \mathrm{~min}$. A mixture of cooked grains and water was ground and dried using the same procedure adopted for the raw beans.

\section{Sequential extraction}

The sequential extraction procedure was described by Naozuka et al. ${ }^{11}$ Masses around $5.0 \mathrm{~g}$ of dried raw and cooked grains were used to solid-liquid sequential extraction with $10 \mathrm{~mL}$ of different extractants: methanol and chloroform $(1: 2 \mathrm{v} / \mathrm{v})$, deionized water, $0.5 \mathrm{~mol} \mathrm{~L}^{-1}$ $\mathrm{NaCl}, 70 \%$ (v/v) ethanol and $0.5 \mathrm{~mol} \mathrm{~L}^{-1} \mathrm{NaOH}$. An orbital shaker was used for extraction for $30 \mathrm{~min}$. The separation of solid phase was carried out after filtration with $0.45 \mu \mathrm{m}$ membrane filter (methanol and chloroform phase) and centrifugation using rotation velocity of $350 \mathrm{rpm}$ for $30 \mathrm{~min}$ (other phases). Proteins and $\mathrm{Fe}$ were determined in the supernatants, except in the methanol/chloroform fraction. This experiment was performed in triplicate.

\section{Total protein determination}

The total protein concentration was determined in water, $\mathrm{NaCl}$, ethanol, and $\mathrm{NaOH}$ fractions by the Bradford method. The spectrophotometer calibration was performed using analytical reference solutions of 4, 6, 8, 10, 12, 16 and $20 \mu \mathrm{g}$ of ovoalbumin in $1.0 \mathrm{~mL}$ of Bradford reagent. Water and $\mathrm{NaCl}$ extracts were diluted 10 -fold and $\mathrm{NaOH}$ fraction was diluted 20 -fold. After dilution, a volume of $100 \mu \mathrm{L}$ of these solutions was used for protein determination. The ethanol portion was not diluted.

\section{MALDI-TOF MS analyses}

The aqueous supernatants of raw and cooked grains were analyzed by MALDI-TOF MS. Aqueous supernatants volumes of $5 \mathrm{~mL}$ were put in a cellulose tubing of $32 \mathrm{~mm}$ diameter (D0530, Sigma-Aldrich) for dialysis in $1.0 \mathrm{~L}$ of deionized water over agitation (100 rpm for $24 \mathrm{~h}$ ). 
The dialyzed aqueous fractions were mixed 1:1(v/v) (raw grains) and 1:10 (v/v) (cooked grains) with a saturated solution of sinapinic acid in 50\% (v/v) acetronitrile and $0.5 \%(\mathrm{v} / \mathrm{v})$ trifluoroacetic acid. This mixture was agitated and subsequently centrifuged using rotation velocity of $5000 \mathrm{rpm}$ for $10 \mathrm{~s}$. An aliquot of $0.5 \mu \mathrm{L}$ was spotted onto a MALDI plate and analyzed by MALDI-TOF MS. ${ }^{11}$

The analyses were performed in the linear mode using an acceleration voltage of $20 \mathrm{kV}$ and a vacuum pressure of $1.5 \times 10^{-6}$ bar. Laser pulses were generated by a nitrogen laser ( 8 pulses per second). Each spot was analyzed twice, accumulating mass spectra composed of a total of approximately 200 laser shots.

\section{Fe determination by GF AAS}

The digested samples and supernatants (water, $\mathrm{NaCl}$, ethanol and $\mathrm{NaOH}$ ) were analyzed by GF AAS. Appropriated dilution in deionized water, ranging from 2 to 50-fold, was performed, depending on the extractant. An aliquot of $10 \mu \mathrm{L}$ was introduced into the graphite tube without chemical modifier and submitted to the heating program described in Table 1. The calibration was done using analytical reference solutions: $10-40 \mu \mathrm{g} \mathrm{L}^{-1}$ of Fe.

Chemical interferences were verified by addition and recovery test. For this, it was added an analytical solution of $40 \mu \mathrm{g} \mathrm{L}^{-1} \mathrm{Fe}$ in all of the extractants, except in the methanol/ chloroform fraction.

\section{Results and Discussion}

\section{Cooking effects on protein concentration}

The protein determination by Bradford method ${ }^{9}$ was carried out in each extractant obtained after the sequential extraction (water, $\mathrm{NaCl}$, ethanol and $\mathrm{NaOH}$ ). The results are shown in the Table 2. It is well discussed in the literature ${ }^{12,13}$ that the extractants water, $\mathrm{NaCl}$, ethanol and $\mathrm{NaOH}$ promoted the separation of different groups of proteins: albumins, globulins, prolamins and glutelins, respectively. ${ }^{12,13}$ The total protein concentration obtained by the masses sum of all extracts revealed that cooking promoted a sensible decrease in the protein content, mainly in the globulins fraction, when compared to the uncooked beans. Previous investigations showed that the total protein concentration ranged from 22.57 to $24.42 \mathrm{~g}$ per $100 \mathrm{~g}$ and from 23.25 to $26.29 \mathrm{~g}$ per $100 \mathrm{~g}$ for raw and cooked beans, respectively. ${ }^{14}$ Comparing these protein value with obtained protein concentration (sum of each fraction), it is possible to observe that low quantity of protein was extracted (6.6-7.0\% and 4.1-4.6\% for raw and cooked beans, respectively). However, it is important to point out that the domestic cooking changed the albumins, prolamins, globulins and glutelins distribution, since high concentrations of albumins, globulins and glutelins were found in raw grains, while albumins and glutelins were the main groups of proteins determined in cooked grains. Such behavior can be associated to the associationdissociation properties of proteins that are expected to be changed by heating, resulting in a decrease of the protein solubility. ${ }^{15}$

Cooking effects on organic compounds (MALDI-TOF MS)

In Figures 1 and 2 are shown the MALDI-TOF MS spectra of aqueous supernatant phases of raw and cooked grains, respectively. Comparing the results, it is possible to observe that the heating procedure decreased the number of compounds of molecular weights ranged from 2 to $17 \mathrm{kDa}\left(1 \mathrm{Da}=1.661 \times 10^{-24} \mathrm{~g}\right) .{ }^{16}$ The raw grains spectrum presented 32 compounds, while in the cooked grains results show only 22 compounds. Cooking resulted in a decrease of the molecular weights of the compounds in the beans. Compounds of molecular weight in the range of 2 and $3.5 \mathrm{kDa}$ were only found in cooked grains. In the cooked beans, four high molecular weight compounds $(12-16 \mathrm{kDa})$

Table 2. Protein and Fe concentration in each protein fractions and digested samples

\begin{tabular}{|c|c|c|c|c|c|c|}
\hline & \multicolumn{3}{|c|}{ Raw grains } & \multicolumn{3}{|c|}{ Cooked grains } \\
\hline & Proteins / (mg g $\left.{ }^{-1}\right)$ & $\mathrm{Fe} /\left(\mu \mathrm{g} \mathrm{g}^{-1}\right) \pm \mathrm{SD}^{\mathrm{b}}$ & $\mathrm{Fe} / \mathrm{P}(\%)^{\mathrm{a}}$ & Proteins / $\left(\mathrm{mg} \mathrm{g}^{-1}\right)$ & $\mathrm{Fe} /\left(\mu \mathrm{g} \mathrm{g}^{-1}\right) \pm \mathrm{SD}^{\mathrm{b}}$ & $\mathrm{Fe} / \mathrm{P}(\%)^{a}$ \\
\hline Albumins & $2.84 \pm 0.02$ & $7.8 \pm 0.8$ & 2.4 & $3.35 \pm 0.03$ & $14 \pm 3$ & 4.6 \\
\hline Globulins & $3.50 \pm 0.03$ & $9.3 \pm 0.7$ & 2.8 & $0.37 \pm 0.02$ & $15 \pm 2$ & 4.9 \\
\hline Prolamins & $0.541 \pm 0.002$ & $0.55 \pm 0.02$ & 0.17 & $0.797 \pm 0.001$ & $0.16 \pm 0.04$ & 0.052 \\
\hline Glutelins & $9.3 \pm 0.1$ & $73 \pm 5$ & 22 & $6.14 \pm 0.04$ & $2.8 \pm 1.3$ & 0.92 \\
\hline Sum $^{\mathrm{c}}$ & $16.1 \pm 0.1$ & $90 \pm 5$ & - & $10.7 \pm 0.1$ & $32 \pm 6$ & - \\
\hline Total $^{\mathrm{d}}$ & - & $331 \pm 21$ & - & - & $305 \pm 43$ & - \\
\hline
\end{tabular}

${ }^{\mathrm{a}} \mathrm{Fe} / \mathrm{P}=\mathrm{Fe}$ associated to proteins, calculated value considering the total Fe concentration. ${ }^{\mathrm{b}} \mathrm{SD}=$ standard deviation $(\mathrm{n}=3)$. ${ }^{\mathrm{c}} \mathrm{Sum}=$ sum of masses of each protein fraction. ${ }^{\mathrm{d}}$ Total $=$ concentration in digested samples. 

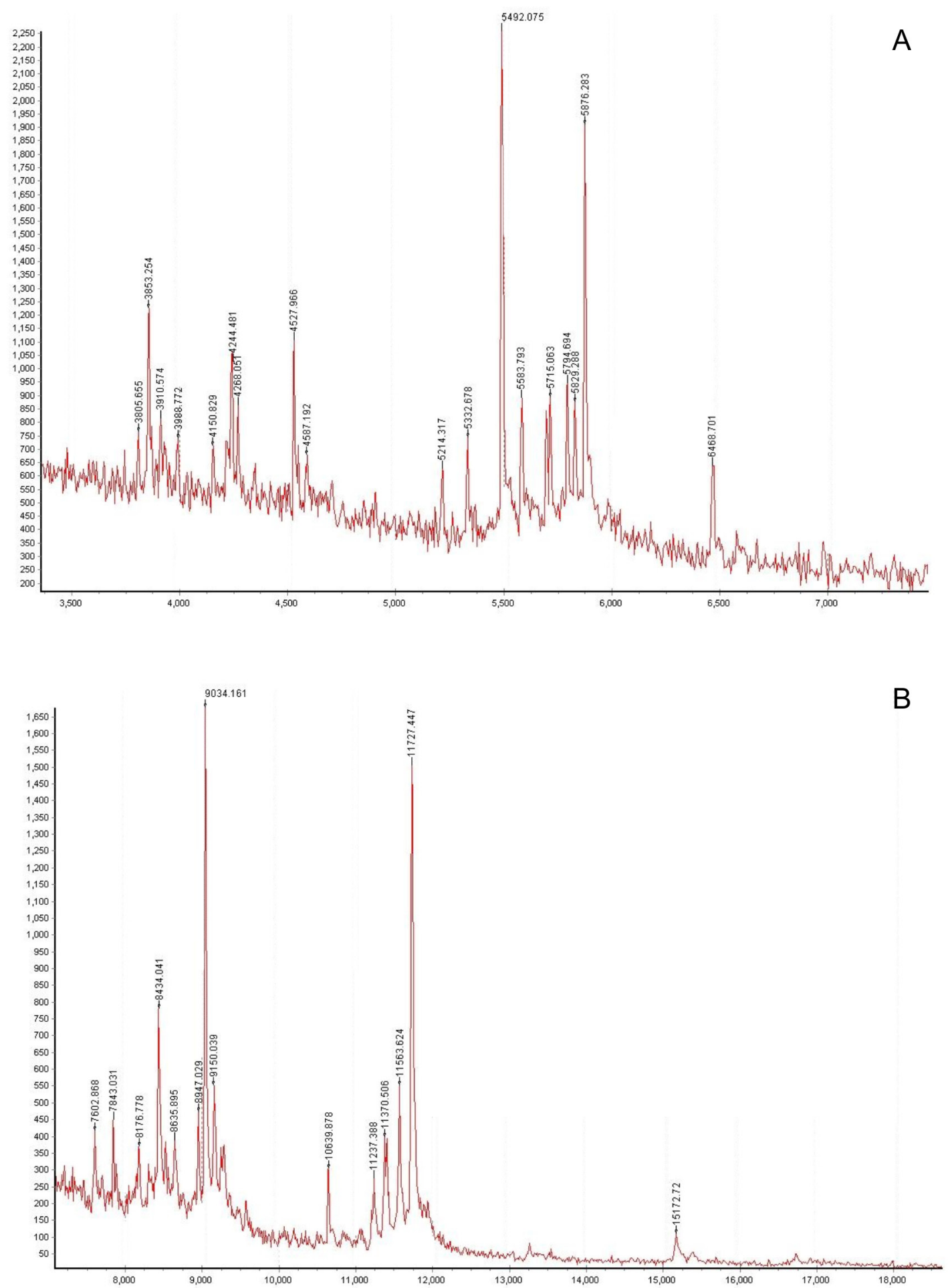

Figure 1. MALDI-TOF spectra of the water-soluble fraction of the raw grains: (A) $3.5-7.0 \mathrm{kDa}$ and (B) 7.5-18 kDa.

were observed in the MALDI TOF MS spectrum (Figure 2). However, in the raw beans only one high molecular weight compound (ca. 15.2 kDa) is observed (Figure 1B). Even as the proteins, some organic compounds can be degraded with cooking procedure, such as tannins and phytate. ${ }^{14}$ Additionally, the association and dissociation of proteins can explain the presence of new compounds of low and high molecular weights after the domestic cooking. In immature seeds of flageolet bean, the cooking improved the high protein quality by destroying or inactivating heat-labile anti-nutritional factors, such as trypsin inhibitors, phytic acid, tannins and oligosaccharides. ${ }^{3,5}$ 


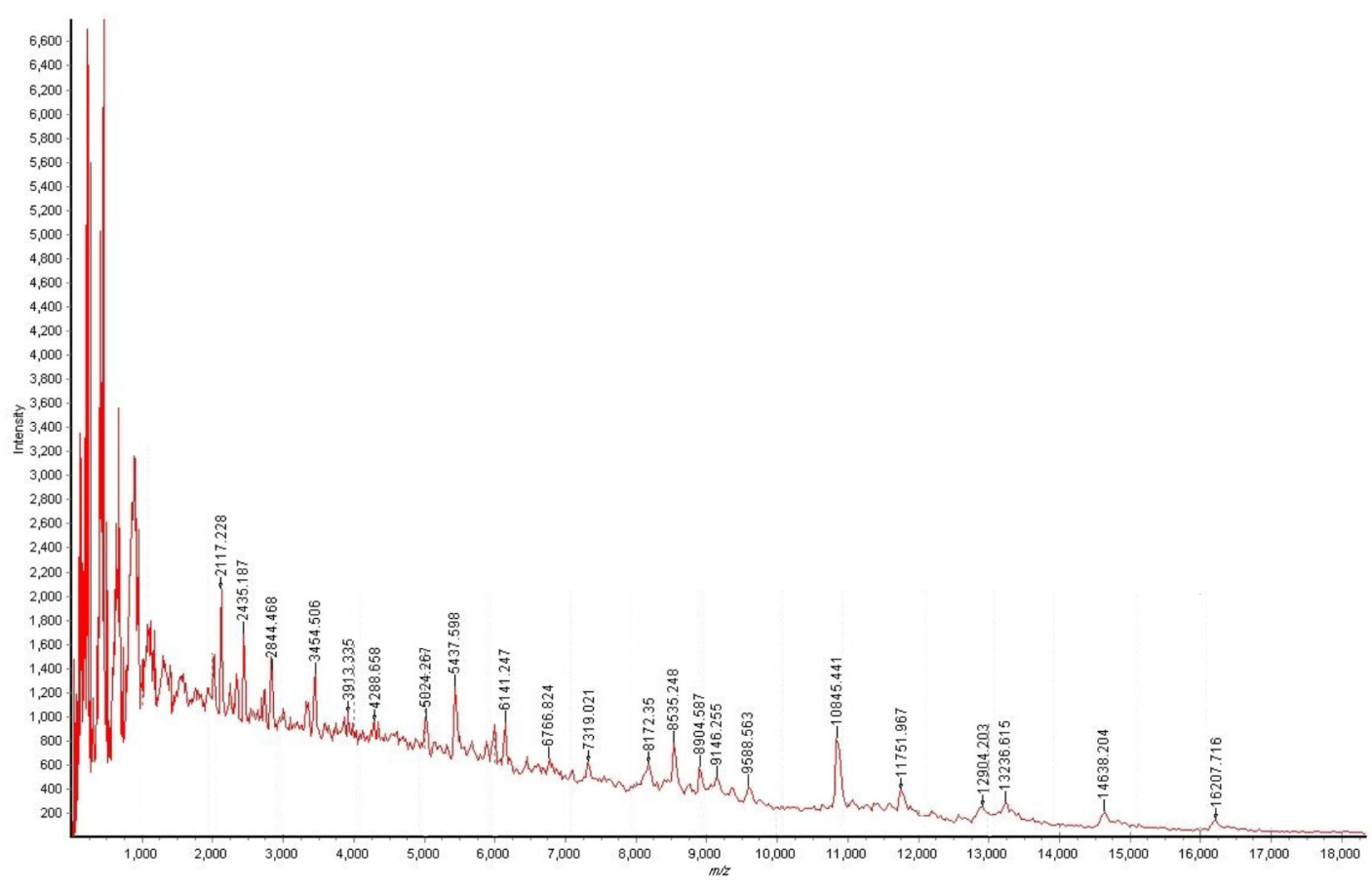

Figure 2. MALDI-TOF spectra of the water-soluble fraction of the cooked grains.

\section{Cooking effects on Fe distribution in different extracts}

Comparing the certified $\left(14.8 \pm 1.8 \mathrm{mg} \mathrm{kg}^{-1}\right)$ with the obtained values $\left(16.8 \pm 3.8 \mathrm{mg} \mathrm{kg}^{-1}\right)$, it is possible to assure that they are coincident at $95 \%$ of confidence interval, according to Student $t$ test. The addition of analytical solution of $\mathrm{Fe}\left(40 \mu \mathrm{g} \mathrm{L}^{-1}\right)$ in the water, $\mathrm{NaCl}$, ethanol and $\mathrm{NaOH}$ extracts of the cooked grains showed recoveries of 89, 123, 96 and 100\%, respectively, which indicate no interference during the $\mathrm{Fe}$ determination by GF AAS. According to NBR ISO/IEC $17025^{17}$ the recovery tolerance ranges from 70 to $120 \%$.

Table 2 shows total $\mathrm{Fe}$ concentration in the digestates and in each fraction (water, $\mathrm{NaCl}$, ethanol and $\mathrm{NaOH}$ ). These results indicate that cooking did not affect Fe concentration. Deionized water used for cooking was the blank.

Comparing the total $\mathrm{Fe}$ concentration (digestates) with the concentration resulting from the sum of masses of Fe associated to the different protein groups (albumins, globulins, prolamins and glutelins), Table 2, it is interesting to observe that 27 and $10 \%$ of the $\mathrm{Fe}$ is associated to proteins (albumins, globulins, prolamins and glutelins) in the raw and cooked beans, respectively. It is evident that the domestic cooking affected the Fe distribution in these protein types. Additionally the heating also altered the Fe percentage in each fraction (Table 2), distinguishing the lost of Fe mainly in the glutelin fraction. It is possible that the heating can release $\mathrm{Fe}$ of the active sites of proteins, since that the transition metal ions, such as $\mathrm{Fe}^{2+}$, have the strongest coordinating interactions, thus being found in the majority of metalloproteins. ${ }^{16}$ Studies showed that cooking may affect macro and micronutrients bioavailability. The digestibility and hence absorption of micronutrients, such as $\mathrm{Fe}$, is improved upon heat processing; with the resultant softening of the food matrix, protein-bound elements is released, thus facilitating its absorption. In addition, heat processing of food also alters the inherent factors that inhibit mineral absorption, such as phytate and dietary fiber. In white beans, the traditional cooking had a positive effect on the bioavailability of $\mathrm{Ca}, \mathrm{Zn}$ and $\mathrm{Fe} .^{6,18}$

In raw grains, it is possible to observe that $\mathrm{Fe}$ is mainly associated to albumins, globulins and glutelins (Table 2). For cooked grains, $\mathrm{Fe}$ is presented in high concentration in albumins and globulins. The cooking procedure altered the association of Fe with glutelins. The main amino acids constituents of albumins, globulins, prolamins and glutelins are rich in sulfur and charged groups such as methionine, cysteine, glutamic acid, arginine, aspartic acid and lysine. ${ }^{11,19-21}$ The metal ions present high-affinity for these amino acids. The cooking effects in the elements distribution in these proteins types can be associated to alteration in the aminoacids content, since that heat procedure causes considerable changes in the composition of numerous chemical constituents, including amino acids, vitamins and minerals, depending on the temperature and time of thermal treatment. ${ }^{3}$ Studies with pulses showed that the long cooking time reduces the nutritive value and the levels of some essential amino acids. ${ }^{5}$ 


\section{Conclusions}

Cooking affected the chemical composition of beans. Total Fe concentration was constant after the heating. Total protein concentration was reduced, indicating the domestic cooking altered the protein structure and consequently their solubility in the different extractants (water, $\mathrm{NaCl}$, ethanol and $\mathrm{NaOH}$ ). Some organic compounds were changed, considering their molecular weights $(<3.5$ and $>12 \mathrm{kDa})$. The cooking also affected the Fe distribution in the different protein types (albumins, globulins, prolamins and glutelins), mainly in the glutelin fraction. The heating is capable of promoting protein denaturation, association-dissociation of proteins, inactivation or destruction of anti-nutritional components and alteration of elemental bioavailability.

\section{Acknowledgments}

The authors are grateful to the Conselho Nacional de Desenvolvimento Científico e Tecnológico (CNPq) and Fundacão de Amparo à Pesquisa do Estado de São Paulo (FAPESP) for financial support and fellowship provided. P.V.O. is thankful to CNPq for the research fellowship.

\section{References}

1. Brigide, P.; Canniatti-Brazaca, S. G.; Food Chem. 2006, 98, 85.

2. Ranilla, L. G.; Genovese, M. I.; Lajolo, F. M.; J. Agric. Food Chem. 2009, 57, 5734.

3. Słupski, J.; Food Chem. 2010, 121, 1171.

4. Saha, S; Singh, G.; Mahajan, V.; Gupta, H. S.; Plant Foods Hum. Nutr. 2009, 64, 174.

5. Wang, N.; Hatcher, D. W.; Tyler, R. T.; Toews, R.; Gawalko, E. J.; Food Res. Int. 2010, 43, 589.

6. Bressani, R.; Food Rev. Int. 1993, 9, 237.
7. Quinteros, A.; Farre, R.; Lagarda, M. J.; Food Chem. 2001, 75, 365.

8. Ramírez-Cárdenas, L.; Leonel, A. J.; Costa, N. M. B.; Reis, F. P.; Food Res. Int. 2010, 43, 573.

9. Bradford, M. M.; Anal. Biochem. 1976, 72, 248

10. Naozuka, J.; Vieira, E. C.; Nascimento, A. N.; Oliveira, P. V.; Food Chem. 2011, 124, 1667.

11. Naozuka, J.; Marana, S. R.; Oliveira, P. V.; J. Food Compos. Anal. 2010, 23, 78.

12. Chunhieng, T.; Pétritis, K.; Elfakir, C.; Brochier, J.; Goli, T.; Montet, D.; J. Agric. Food Chem. 2004, 52, 4318.

13. Naozuka, J.; Oliveira, P. V.; J. Braz. Chem. Soc. 2007, 18, 1547.

14. Ramírez-Cárdenas; Leonel, A. J.; Costa, N. M. B.; Cienc. Tecnol. Aliment. 2008, 28, 200.

15. Carbonaro, M.; Vecchini, P.; Carnovale, E.; J. Agric. Food Chem. 1993, 41, 1169.

16. Garcia, J.S.; Magalhães, C. S.; Arruda, M. A. Z.; Talanta 2006, $69,1$.

17. Burin, R.; Burin, V. M.;Taha, P.; Bordignon-Luiz, M. T.; Ciênc. Tecnol. Aliment. 2008, 28, 973.

18. Lombardi-Boccia, G.; Santis, N.; Lullo, G. D.; Carnovale, E.; Food Chem. 1995, 53, 191.

19. Garcia, R. M.; Arocena, R. V.; Laurena, A. C.; Tecson-Mendoza, E. M.; J. Agric. Food Chem. 2005, 53, 1734.

20. Moreno, F. J.; Jenkins, J. A.; Mellon, F. A.; Rigby, N. M.; Robertson, J. A.; Wellner, N.; Mills, E. N. C.; Biochim. Biophys. Acta 2004, 1698, 175

21. Sun, S. S. M.; Leung, F. W.; Tomic, J. C.; J. Agric. Food Chem. 1987, 35, 232.

Submitted: October 25, 2010

Published online: November 8, 2011

FAPESP has sponsored the publication of this article. 